\title{
Analisis Pendapatan Usahatani Padi Organik dan Kontribusinya terhadap Pendapatan Rumah Tangga di Kecamatan BTS Ulu Kabupaten Musi Rawas
}

\section{Income Analysis of Organic Rice Farming and Its Contribution to Households' Income in BTS Ulu District Musi Rawas Regency}

\author{
Ira Primalasari ${ }^{*}$, May Shiska Puspitasari ${ }^{1}$ \\ ${ }^{1}$ Program Studi Agribisnis / Universitas Musi Rawas Lubuklinggau \\ *E-mail : iraprimalasari20@gmail.com
}

\begin{abstract}
This study aims to analyze amount of income and calculate the contribution of organic rice farming to household income in Suka Makmur Village, BTS Ulu District. The research was conducted in Suka Makmur Village, BTS Ulu District. The research was conducted in September-October 2020. This location was chosen because it has a large number of organic rice farmers and has been used as a source of household income in Suka Makmur Village. Respondents in this study were taken based on purposive sampling method where all members of the population were used as respondent data in the study. This is primary data. Primary data in this study were obtained through interviews with questionnaires for organic rice farmers. Interviews were conducted with the aim of obtaining information directly from the respondents, which were related to the research topic. The number of samples of organic rice farmers were 77 respondents who were administrators and members of the organic rice group. This research used descriptive quantitative data analysis. The results showed that the average income of organic rice farmers in Suka Makmur Village, BTS Ulu District was 34,100,000 / year. The largest contribution of organic rice farming income to family income was $34.12 \%$. This shows that the results of organic rice farming are the main source of income to meet their daily needs.
\end{abstract}

Keywords: Contribution of income, income, organic rice

Disubmit : 6 Pebruari 2021, Diterima: 1 Juli 2021, Disetujui : 29 Oktober 2021

\section{PENDAHULUAN}

Bidang pertanian merupakan salah satu penunjang untuk pemulihan ekonomi bangsa. Sumber pendapatan masyarakat di Indonesia terutama di wilayah pedesaan masih tergantung dengan sektor pertanian, salah satunya subsektor pertanian tanaman pangan yakni tanaman padi (Anton, M. \& Marhawati, 2016). Tanaman padi merupakan salah satu tanaman pangan, sehingga sudah tidak familiar lagi bahwa banyak masyarakat memilih tanaman padi menjadi beras sebagai bahan pokok dalam kehidupan (Putri, 2018). Dalam kehidupan bermasyarakat padi menjadi komoditi yang sangat dibutuhkan, sehingga memiliki nilai strategis yang sangat tinggi. Padi organik merupakan tnaman padi yang dihasilkan dengan menggunakan sistem budidaya organik. Menurut (Hartati, 2018)adanya pertanian organik memiliki alasan 
tersendiri dalam aspek kualitas konsumsi dalam jangka panjang manusia, aspek kelestarian lingkungan, aspek ideologis dan aspek nilai tambah. (Puspitasari, 2016), juga menyatakan bahwa adanya pertanian organik dapat mengurangi pencemaran lingkungan, salah satunya yaitu pencemaran zat kimia. Hal ini dikarenakan padi organik merupakan produk yang sehat, aman dan ramah lingkungan. Salah satu wilayah penghasil padi organik yaitu di Kecamatan BTS Ulu Kabupaten Musi Rawas.

Kecamatan BTS Ulu terutama di Desa Suka Makmur merupakan salah satu desa penghasil beras organik di Kabupaten Musi Rawas. Sebagian masyarakat telah lama membudidayakan pertanian organik terutama padi organik. Padi Organik di Desa Suka Makmur menjadi sumber pendapatan utama untuk memenuhi kebutuhan hidupnya. Padi organik menjadi salah satu usahatani yang dikembangkan di daerah tersebut karena padi organik tidak mengandung unsur zat kimia atau zat-zat yang sangat merugikan dan berbahanya untuk kesehatan tubuh manusia. Sehingga padi organik yang diolah menjadi menjadi beras organik menjadi kebutuhan utama untuk dikonsumsi masyarakat.

Pendapatan dapat diartikan sebagai hasil upah/gaji dari balas jasa yang diterima atau yang didapatkan oleh seseorang yang telah melaksanakan kewajibanya. Menurut (Sukirno, 2004), pendapatan juga dapat dimaknai sebagai segala sesuatu yang diterima oleh seseorang sebagai hasil kerja keras yang telah dilakukan baik berupa kegiatan fisik maupun non fisik. Pendapatan usahatani yang rendah dan kurang untuk mencukupi kebutuhan rumahtangga petani, akan mengakibatkan sebagian anggota rumah tangga mencari alternatif sumber penghasilan yang lain. Sumber pendapatan yang lain yang dapat dilakukan, misalnya dengan melakukan inovasi usahatani selain itu juga menambah waktu tenaga kerja untuk bekerja diluar usahatani, sehingga akan meningkatkan penghasilan dalam suatu keluarga. Pendapatan yang diperoleh dari berbagai sumber pekerjaan akan berpengaruh terhadap distribusi pendapatan. Distribusi pendapatan merupakan pembagian penghasilan/pendapatan di dalam suatu masyarakat.

Berdasarkan latar belakang di atas, maka rumusan masalah dalam penelitian yaitu untuk mengetahui pendapatan usahatani padi organik dan kontribusinya terhadap pendapatan rumahtangga petani maka tujuan penelitian ini adalah menghitung pendapatan usahatani padi organik dan kontribusinya terhadap pendapatan rumah tangga petani padi organik di Desa Suka Makmur Kecamatan BTS Ulu Kabupaten Musi Rawas.

\section{METODE PENELITIAN}

\section{Metode Penentuan Lokasi}

Lokasi penelitian ini dilakukan di Desa Suka Makmur Kecamatan BTS Ulu. Penelitian dilakukan pada bulan September-Oktober 2020. Lokasi dipilih secara purposive dengan pertimbangan bahwa lokasi ini memiliki jumlah petani padi organik yang besar dan telah dijadikan sumber pendapatan rumah tangga di Desa Suka Makmur.

\section{Metode Penarikan Sampel dan Sumber Data}

Sampel penelitian ini merupakan petani padi organik di Kelompok Tani Handayani Desa Suka Makmur. Penentuan responden dalam penelitian ini menggunakan purposive sampling yang semua anggota populasi dijadikan responden. Jumlah sampel petani padi organik sebanyak 77 responden yang merupakan pengurus dan anggota kelompok padi organik. Jumlah dipilih sesuai dengan pertimbangan bahwa hanya di wilayah Kecamatan BTS Ulu terdapat petani penghasil padi organik. Data yang digunakan dalam penelitian ini adalah data primer. Data primer dalam penelitian ini diperoleh melalui wawancara dengan kuesioner petani padi organik. Wawancara penelitian dilakukan dengan tujuan untuk memperoleh informasi secara langsung dari responden penelitian, yang berkaitan dengan topik penelitian.

\section{Metode Analisis Data}


Penulis: Ira P, dkk. Analisis Pendapatan Usahatani Padi Organik dan Kontribusinya terhadap Pendapatan Rumah Tangga di Kecamatan BTS Ulu Kabupaten Musi Rawas

Penelitian ini menggunakan analisis data secara deskriptif kuantitatif (Yolandika, Nurmalina and Suharno, 2017) (Yolandika, Lestari and Situmorang, 2015). Berikut merupakan analisis yang digunakan dalam penelitian ini:

\section{Analisis Pendapatan usahatani padi organik}

Untuk menjawab tujuan pertama maka analisis yang digunakan yaitu dengan rumus pendapatan (Listiani, 2019) berikut :

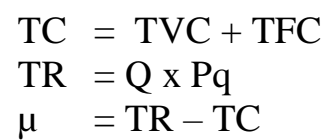

Ket:

TC $\quad$ : Total cost/biaya total produksi padi oraganik (Rp)

TVC : Total variable cost / biaya variabel total padi organik(Rp)

TFC : Total fixed cost/ biaya tetap total padi organik (Rp)

I : income (pendapatan padi organik)

TR : total revenue (penerimaan total padi organik)

TC : total cost (biaya total padi organik)

Analisis Kontribusi pendapatan usahatani padi organik terhadap pendapatan rumah tangga Desa Suka Makmur. Untuk menjawab tujuan ke dua maka analisis yang digunakan yaitu:

Kontribusi $=\frac{\text { pendapatan usahtani pada sawah organik }}{\text { Pendapatan keluarga }} \times 100 \%$ (Anton, M. \& Marhawati, 2016)

\section{HASIL DAN PEMBAHASAN}

Karakteristik Responden

Sampel dalam penelitian ini berjumlah 77 orang petani padi dengan dasar pertimbangan petani yang mengusahakan tanaman padi organik. Karakteristik menggambarkan secara deskriptif keadaan responden dalam penelitian. karakteristik responden yang diteliti dalam penelitian ini yaitu berupa umur, jumlah tanggungan anggota keluarga dan tingkat pendidikan responden.

Umur responden petani organik berpengaruh terhadap kemampuan tenaga dalam melakukan dan mengolah usahatani padi. Secara umum rata-rata umur responden di wilayah penelitian memiliki umur yang produktif untuk bekerja. Dalam hal ini petani secara fisik masih memiliki kemampuan yang besar dalam mengolah lahan usahataninya. Berdasarkan hasil penelitian, umur terbanyak pada responden berkisar 45-55 Tahun.

Tabel 2. Jumlah responden berdasarkan umur

\begin{tabular}{ccc}
\hline Umur & Jumlah Responden & Presentase $(\%)$ \\
\hline $34-44$ & 21 & 27.27 \\
$45-55$ & 46 & 59.74 \\
$56-66$ & 10 & 12.99 \\
\hline Jumlah & 77 & 100 \\
\hline
\end{tabular}

Sumber : Data Primer diolah, 2019 
Berdasarkan hasil penelitian di atas menunjukkan bahwa petani yang memiliki kisaran umur 45-55 tahun sebesar 59,74\% atau 46 orang. Hal ini berarti bahwa petani di wilayah penelitian memiliki umur yang sangat produktif, hal ini juga berkaitan dengan tingkat pengalaman berusahatani yang lebih lama. Pengalaman berusahatani yang lebih lama juga akan berpengaruh terhadap hasil usahatani yang digarapnya.

Jumlah tanggungan anggota keluarga merupakan seseorang yang tinggal dalam satu rumah. Jumlah tanggungan keluarga di setiap rumahtangga berbeda-beda. Jumlah tanggungan anggota keluarga juga merupakan salah satu faktor penting dalam menunjang keberhasilan berusahatani. Semakin besar jumlah anggota keluarga dalam suatu rumahtangga, maka semakin besar juga tenaga yang tercurahkan untuk membantuk melakukan kegiatan usahataninya. Namun sebaliknya semakin dikit jumlah tanggungan keluarga dalam suatu rumahtangga, maka tenaga yang tercurahkan dalam kegiatan usahatani juga akan berkurang.

Tabel 3. Jumlah tanggungan keluarga petani padi organic

\begin{tabular}{ccc}
\hline Jumlah tanggungan keluarga & Jumlah petani organik & Presentase (\%) \\
\hline $1-3$ & 24 & 31.17 \\
$5-7$ & 53 & 68.83 \\
\hline Jumlah & 77 & 100 \\
\hline
\end{tabular}

Sumber : Data Primer diolah, 2019

Tabel 3 di atas menunjukkan jumlah tanggungan keluarga di wilayah penelitian. hasil penelitian bahwa 68,83\% rumah tangga di wilayah penelitian memiliki jumlah tanggungan keluarga sebanyak 5-7 orang. Besarnya jumlah tanggungan keluarga akan mempengaruhi seberapa besar pendapatan yang diperoleh, Hal ini dikarenakan jumlah tanggungan yang ada dalam sebuah keluarga akan membantu bekerja dan mendapatkan sumber pendapatan dari hasil kerja yang telah dilakukannya.

Pendidikan merupakan lamanya seseorang belajar di bangku sekolah. Tingkat pendidikan akan mempengaruhi kemampuan dalam mengelola usahatani. Tingginya tingkat pendidikan yang ditempuh oleh petani organik, maka akan semakin mudah dalam menerima inovasi dan teknologi untuk mengolah usahatani padi organik. Hal ini juga berkaitan dengan pengalaman ataupun lamanya seorang petani padi organik dalam mengelola usahataninya. Rincian untuk tingkat pendidikan petani padi organik adalah sebagai berikut:

Tabel 4. Tingkat Pendidikan Petani Padi Organik

\begin{tabular}{ccc}
\hline Tingkat Pendidikan & Jumlah petani padi organik & Presentase (\%) \\
\hline SD & 33 & 42,86 \\
SMP & 23 & 29,87 \\
SMA & 21 & 27,27 \\
\hline Jumlah & 77 & 100 \\
\hline
\end{tabular}

Sumber : Data Primer diolah, 2019

Hasil penelitian pada tabel 4 di atas, menunjukkan rata-rata tingkat pendidikan yang telah ditempuh oleh petani padi organik. Hasil penelitian menunjukkan $42,86 \%$ petani padi telah menempuh pendidikan SD. Sebanyak $29,87 \%$ petani telah menempuh pendidikan SMP dan sebanyak $27,27 \%$ petani telah menyelesaikan pendidikan tingkat SMA. Hasil tersebut menunjukkan rata-rata petani padi organik telah 
menempuh pendidikan pokok yaitu minimal mampu berhitung, membaca dan menulis. Seseorang yang memiliki pendidikan yang cukup akan mampu merubah pola pikir sehingga akan lebih maju dan berkembang dalam mengembangkan usahataninya.

\section{Harga Jual Beras Organik}

Di Desa Suka Makmur petani padi organik menjual hasil usahataninya berupa beras organik dengan harga jual yaitu sebesar Rp. 15.000/Kg dalam bentuk beras. Menurut (Zaini, A., 2018), beras organik memiliki harga yang tinggi, hal ini dikarenakan selain merupakan pangan yang sehat, juga produksi beras organik masih terbatas. Harga jual ini berubah sesuai dengan harga pasar. Sistem penjualan yang dilakukan oleh masyarakat adalah dengan sistem cash atau tunai antara pembeli dan penjual.

\section{Biaya Tenaga Kerja}

Biaya tenaga kerja yang digunakan dalam setahun di Desa Suka Makmur Kecamatan BTS Ulu untuk mengelola usahataninya memiliki rata-rata sebesar Rp. 4.422.400. Biaya tenaga kerja meliputi biaya pengolahan lahan, penyemaian benih, perbaikan pematang, penanaman, penyiangan, pemupukan, penyemprotan, pemanenan. pembayaran upah tenaga kerja di wilayah penelitian menggunakan sistem tunai.

\section{Total Biaya Usahatani Padi Organik}

Kegiatan usahatani padi organik tidak terlepas dari biaya produksi yang digunakan, biaya produksi adalah biaya yang digunakan dalam kegiatan usahatani padi organik dalam penelitian ini terdiri dari biaya tetap dan biaya variabel. Menurut (Hasang, 2015) biaya tetap merupakan biaya yang tidak berubah dalam satu proses produksi walaupun selalu digunakan terus-menerus. Sedangkan biaya variabel adalah biaya yang besar kecilnya dipengaruhi oleh hasil produksi. Berdasarkan tabel di atas, biaya produksi yang digunakan adalah keseluruhan biaya dalam kegiatan proses produksi selama satu tahun. Rata-rata biaya tetap yang digunakan sebesar Rp. 252.760/Tahun. Biaya tetap berupa biaya penyusutan alat usahatani.

Alat-alat yang dimaksud adalah alat-alat yang digunakan dalam kegiatan usahatani padi organik. Sedangkan untuk biaya variabel terdiri dari biaya saprodi (benih, pupuk, pestisida) dan biaya tenaga kerja (pengolahan lahan, penyemaian benih, perbaikan pematang, penanaman, penyiangan, pemupukan, penyemprotan, pemanenan). Pendapatan yang diterima oleh petani padi organik berbeda-beda tergantung dengan jumlah produksi yang dihasilkan. Pendapatan usahatani merupakan sebagian dari pendapatan keluarga petani (Jemadi dan Siti, 2011). Rincian biaya produksi yang digunakan pada usahatani padi organik adalah sebagai berikut:

Tabel 6. Rata-rata biaya produksi usahatani padi organik

\begin{tabular}{ccccc}
\hline $\mathrm{n}$ & Biaya Tetap & \multicolumn{2}{c}{ Biaya Variabel } & \multirow{2}{*}{$\begin{array}{c}\text { Total Biaya } \\
\text { Produksi }\end{array}$} \\
\cline { 2 - 4 } & Biaya Peralatan Pertanian & Biaya Saprodi & Biaya Tenaga Kerja & 7.660 .000 \\
\hline 77 & 252.760 & 2.984 .840 & 4.422 .400 & \\
\hline
\end{tabular}

Sumber : Data Primer diolah, 2019.

Hasil penelitian menunjukkan bahwa rata-rata total pendapatan yang diperoleh petani padi sebesar Rp. 34.100.000/tahun. Jumlah produksi yang dihasilkan oleh petani padi organik akan mempengaruhi jumlah pendapatan yang diterima. Hal ini dikarenakan tinggi rendahnya pendapatan yang diperoleh tergantung dengan harga jual padi dan jumlah produksi padi yang dihasilkan. Semakin tinggi harga jual dan jumlah produksi yang dihasilkan maka akan pendapatan akan meningkat, namun sebaliknya semakin rendah harga jual dan jumlah produksi yang dihasilkan maka akan mengalami penurunan pendapatan. Untuk padi organik 
ini memiliki nilai jual yang tinggi karena memiliki keunggulan beras yang bebas pestisida dan bahan kimia lainnya, sehingga merupakan beras yang sehat dan beras organik ini telah bersertifikasi sehingga menambah nilai jual beras ini. selain itu pola konsumsi masyarakat saat ini yang banyak memilih pola hidup sehat sehingga menjadikan beras organik ini menjadi alternativ pilihan yang tepat untuk dikonsumsi.

Tabel 7 . Rata-rata pendapatan usahatani padi organik/Tahun

\begin{tabular}{lcrccc}
\hline $\mathrm{N}$ & Total Biaya Produksi & Produksi & Harga Jual beras & Penerimaan & Pendapatan \\
\hline 77 & 7.660 .000 & 2.784 & 15.000 & 41.760 .000 & 34.100 .000 \\
\hline
\end{tabular}

Sumber : Data Primer diolah, 2019.

\section{Kontribusi Pendapatan Usahatani Padi Organik}

Menurut (Bulanta, 2019) kontribusi usahatani padi terhadap pendapatan merupakan tambahan pemasukan pendapatan yang diterima oleh patani. Kontribusi merupakan besar kecilnya bagian pendapatan yang disumbangkan dari usahatani padi organik terhadap total pendapatan usahatani keluarga di Desa Suka Makmur Kecamatan BTS Ulu. Sumber pendapatan di BTS terdiri dari pendapatan yang berasal dari usahatani padi organik dan sumber pendapatan lain yaitu non usahatani. Untuk mengetahui kontribusi pendapatan dari usahatani padi organik, maka data yang dibutuhkan yaitu data jumlah pendapatan dari usahatani padi organik dan pendapatan keluarga petani secara keseluruhan. Pendapatan yang digunakan oleh keluarga petani untuk memenuhi kebutuhan hidupnya biasanya menggunakan pendapatan terbesar yang diperolehnya. Berikut ini merupakan kontribusi pendapatan di Desa Suka Makmur Kecamatan BTS Ulu:

Tabel 8. Kontribusi pendapatan petani padi organic

\begin{tabular}{llrr}
\hline No & Sumber Pendapatan & Pendapatan (Rp) & Kontribusi (\%) \\
\hline 1 & Usahatani Padi Organik & 34.100 .000 & 34,13 \\
2 & Pedagang & 26.645 .000 & 26,66 \\
3 & PNS & 23.900 .000 & 23,91 \\
4 & Lain-lain & 15.296 .000 & 15,30 \\
\hline & Jumlah & 99.941 .000 & 100 \\
\hline
\end{tabular}

Sumber : Data Primer diolah, 2019

Berdasarkan tabel di atas menunjukkan kontribusi pendapatan masyarakat Desa Suka Makmur terdiri dari usahatani padi , pedagang dan PNS. Kontribusi pendapatan usahatani padi organik terhadap pendapatan rumahtangga petani yaitu mencapai 34,13\%. sedangkan kontribusi pendapatan pedagang sebesar 26,66\%. Untuk PNS kontribusi pendapatan sebesar $23,91 \%$ dan kontribusi pendapatan yang lain $15,30 \%$. Hal ini berarti bahwa usahatani padi organik memberikan kontribusi terbesar dibandingkan dengan sumber pendapatan yang lain. Hal ini sejalan dengan penelitian (Maluhima, S., M. Memah dan Martha, 2020), bahwa pendapatan petani sebagian besar berasal dari usahatani padi . Tidak dapat dipungkiri bahwa usahatani padi menjadi sumber pendapatan bagi masyarakat terutama di Desa Suka Makmur Kecamatan BTS Ulu. 
Penulis: Ira P, dkk. Analisis Pendapatan Usahatani Padi Organik dan Kontribusinya terhadap Pendapatan Rumah Tangga di Kecamatan BTS Ulu Kabupaten Musi Rawas

\section{KESIMPULAN}

Rata-rata pendapatan petani padi organik yang diperoleh petani di Desa Suka Makmur Kecamatan BTS Ulu sebesar Rp 34.100.000/Tahun. Kontribusi pendapatan usahatani padi organik terhadap pendapatan rumahtangga petani padi organik terbesar yaitu mencapai $34,12 \%$. Hal ini menunjukkan bahwa hasil usahatani padi organik menjadi sumber utama penghasilan untuk memenuhi kebutuhan hidupnya.

Lahan pertanian untuk padi organik sangat berpotensi dan memiliki prospek pertanian yang maju untuk masa depan, baik untuk warga masyarakat khususnya dan bangsa, sehingga dalam hal ini dukungan dan support dari pemerintah sangat dibutuhkan. Sehingga dapat dilakukan perluasan untuk luas lahan usahatani padi organik di wilayah tersebut.

\section{DAFTAR PUSTAKA}

Anton, M. \& Marhawati, G. (2016) 'Kontribusi Usaha Tani Padi Sawah Terhadap Pendapatan Usaha Tani Keluarga di Desa Ogoamas II Kec Sojol Utara Kabupaten Donggala’, Agrotekbis, 4(1), pp. 106-112.

Bulanta, O. (2019) 'Kontribusi Usahatani Padi Terhadap Pendapatan Keluarga di Kelurahan Taratara Satu Kecamatan Tomohon Barat Kota Tomohon', Agri. Sosial Ekonomi Unsrat, 15(2), pp. $235-242$.

Hartati, A. (2018) 'Distribusi Pendapatan Petani Padi Organik di Kabupaten Banyumas Provinsi Jawa Tengah', Journal lppm.unsoed, 8(1), pp. 64-72.

Hasang, I. dan N. (2015) 'Kontribusi Usahatani Padi Terhadap Pendapatan Petani di Kecamatan Palateang Kabupaten Pinrang', Jurnal Economs, 13(1), pp. 27-34.

Jemadi dan Siti, N. H. (2011) 'Analisis Tentang Tingkat Pendapatan Usahatani Padi dan Mendong Serta Kontribusinya Terhadap Pendapatan Keluarga, di Kecamatan Minggir Kabupaten Sleman Yogyakarta', Jurnal MAKSIPRENEUR, 1(1), pp. 71-82.

Listiani, E. a. (2019) 'Analisis Pendapatan Usahatani Padi di Kecamatan Mlonggo Kabupaten Jepara. Agrisocionomics', Jurnal Sosial Ekonomi dan Kebijakan Pertanian, 3(1), pp. 50-58.

Maluhima, S., M. Memah dan Martha, M. S. (2020) 'Kontribusi Usahatani Padi Terhadap Pendapatan Keluarga Petani di Desa Amongena II Kecamatan Langowan Timur Kabupaten Minahasa', Journal of Agribusiness and Rural Development, 1(4), pp. 515-523.

Puspitasari, M. (2016) 'Analysis of Factors Affecting Organic Rice Production in Musi Rawas Regency', in The 1 'St International Conference on Green Development-University of Jambi. Jambi, pp. 13-21.

Putri, C. K. dan T. (2018) 'Analisis Pendapatan Dan Tingkat Kesejahteraan Rumah Tangga Petani Padi Sawah Berdasarkan Luas Lahan di Desa Sindangsari Kecamatan Banjasari, Kabupaten Ciamis, Provinsi Jawa Barat.', Jurnal Ilmiah Mahasiswa Agroinfo Galuh, 4(3), pp. 927-935.

Sukirno (2004) 'Pengantar Teori Makroekonomi’, in Edisi ketiga. Jakarta: Raja Grapindo Persada. 
Yolandika, C., Lestari, D. A. H. and Situmorang, S. (2015) 'Keberhasilan Koperasi Unit Desa (KUD) Mina Jaya Kota Bandar Lampung Berdasarkan Pendekatan Tripartite', Jurnal Ilmu-Ilmu Agribisnis, 3(4), pp. 385-392.

Yolandika, C., Nurmalina, R. and Suharno, S. (2017) 'Rantai Pasok Brokoli di Kecamatan Lembang Kabupaten Bandung Barat dengan Pendekatan Food Supply Chain Networks', Jurnal Penelitian Pertanian Terapan, 16(3), pp. 155-162. doi: 10.25181/jppt.v16i3.93.

Zaini, A., E. H. dan A. (2018) 'Pengembangan Beras Organik. Prosiding Seminar Nasional Fakultas Pertanian Universitas Jambi.', in. Jambi, pp. 616-633. 